\title{
Tables, Maps, and Figures
}

Tables

2.I Administrative structures in Sama Dua 46

2.2 Regulations of a seuneubok 5 I

2.3 Protected and cultivation areas in Sama Dua district according to district spatial plan $\quad 72$

3.I Administrative structures in Menggamat 90

3.2 Forest uses and associated institutional arrangements in Menggamat $\quad 92$

3.3 Self-generated district government incomes (PAD), South Aceh $\quad 108$

3.4 Total district government budget, South Aceh IO9

4.I Administrative structures in the Alas valley $\quad$ I55

4.2 State forest in Southeast Aceh I60

4.3 Land use in Badar sub-district I6I

$\begin{array}{ll}\text { Maps } & \\ \text { I Northern Sumatra xxviii }\end{array}$ 
2 The Leuser Ecosystem xix

3 Indonesia. $\quad \mathbf{x x x}$

4 South and Southeast Aceh: sub-district boundaries 26

5 South Aceh: forest boundaries 27

6 Sama Dua sub-district boundaries $\quad 44$

$7 \quad$ North Kluet sub-district: forest concession and national park boundaries

8 Jambur Lak-Lak village, Badar sub-district, Southeast Aceh: forest boundaries and hamlets

Figures

I Tapaktoean port, Atjeh, circa I900 52

2 Three heads of the Soesoh principality 52

3 Heavily eroded hillsides behind Sama Dua 53

$4 \quad$ View eastward from a hill behind Sama Dua 53

$5 \quad$ Nutmeg factory, South Aceh 54

6 The author with a seuneubok head, Sama Dua 54

$7 \quad$ Mace and nutmeg drying in the sun 55

8 Wholesaler inspecting nutmeg stones drying outside his house, Sama Dua $\quad 55$

9 Nutmeg tree after the "trunk borer" infestation 56

Io The Kluet River valley, Menggamat 126

I I Menggamat village land $\quad$ I26

I2 Secondary forest in village lands, Menggamat $\quad$ I27

I3 "Limited production forest," Menggamat $\quad$ I27

I4 Timber extracted via the river, Menggamat $\quad \mathbf{2 8}$

I5 Timber merchant, Tapaktuan $\quad$ I28

I6 The southern end of the Alas valley, Southeast Aceh $\quad 172$ 
I7 Candlenut gardens along the Alas River in the national park bufferzone, Badar Sub-district, Southeast Aceh

I 8 Opening a new kebun within the national park "enclave," Badar Sub-district, Southeast Aceh

I9 Deforested hillside, southern end of the Alas valley, Southeast Aceh

20 A Leuser Development Programme field office, Southeast Aceh

2 Ketambe Research Station, Gunung Leuser

National Park, Badar Sub-district

22 An enclave village within the national park, with rice, candlenut, and coffee drying on the

Kutacane-Blangkejeren road, Badar sub-district, Southeast Aceh

23 Cooking nilam leaves to produce patchouli oil, Badar sub-district, Southeast Aceh

24 A tobacco ladang, Gayo Lues, Southeast Aceh

25 Buying rattan in the market. Blangkejeren, Southeast Aceh 
